\title{
The nutritive value of maize foggage for ewes and their lambs in the North Eastern Free State
}

\author{
D.J. Kriek, J.E.J. Du Toit and M.D. Fair \\ Dept of Animal Science, University of the Orange Free State, PO Box 339, Bloemfontein, 9300 \\ e-mail:erhard@landbou.uovs.ac.za
}

\section{Introduction}

The nutritive value of maize foggage cultivated on a low yield potential soil in the North Eastern Free State was examined in a production study with Dohne Merino ewes and their lambs. Four yellow maize cultivars with the same growth season length but differing in prolificacy, namely PAN 6364 (high prolific), SNK 2950 (semi high prolific), CRN 4512 (semi low prolific) and CRN 4502 (low prolific) were cultivated to be grazed as maize foggage by lactating ewes and their lambs. Maize cultivars differ greatly in grain yield potential and various other characteristics but little is known concerning the nutritive value of cultivars when utilized as maize foggage and the effect this might have on various aspects of sheep production.

\section{Material and Methods}

The study was conducted between 1 November 1996 and 5 August 1997. The four cultivars were planted in a fully randomised complete block design on 14 November 1996 and were fertilized according to the planned grain yield of $2.5 \mathrm{t} / \mathrm{ha}$ with $35 \mathrm{~kg} \mathrm{~N} / \mathrm{ha}, 15.65 \mathrm{~kg} \mathrm{P} / \mathrm{ha}$ and $10.43 \mathrm{~kg} \mathrm{~K} / \mathrm{ha}$. Experimental animals consisted of 120 Dohne Merino ewes and their lambs. Lambs were born on Themeda-Cymbopogon veld during March 1997 and ewes were introduced onto maize foggage during Week 5 of lactation on 5 May 1997. The maize was grazed at a stocking rate of 15 ewes and lambs/ha during a 90-day grazing period (Moore \& Müller, 1994). A true protein-acidosis lick was supplied to ewes to prevent acidosis (Schoonraad, 1985; Moore \& Müller, 1994). Lick was supplied on an equal basis between cultivars. DM-yield/ha and grain yield/ha for cultivars were determined. Residues not utilized by sheep during the grazing period were determined after completion of the grazing period. Chemical composition of grazing material was examined by use of feed samples collected by esophageal fistulated ewes. Ewes were weighed every two weeks and lambs every week. Milk production of twenty ewes was determined during Week 1, 3, 5, 7, 9, 11, 13 and 15 of lactation by use of the oxytocin method (Ferreira, 1992). Wool fibre diameter of ewes was examined by gathering wool mid-rib samples before and after completion of the grazing period. Multiple comparisons using Tukey's method were used to determine which cultivars differed significantly.

\section{Results and Discussion}

Estimated DM-yield, grain yield and percentage DM utilized by sheep are presented in Table 1.

Table 1 Estimated DM-yield, grain yield and percentage DM utilized by sheep

\begin{tabular}{llllll}
\hline & 1) PAN 6364 & 2) SNK 2950 & 3) CRN 4512 & 4) CRN 4502 & SE \\
\hline DM-yield (t/ha) & 4.996 & 6.36 & 5.126 & 4.381 & 1.069 \\
Grain yield (t/ha) & 2.009 & 2.782 & 2.146 & 2.423 & 0.56 \\
DM utilized (\%) & 70.08 & 67.13 & 62.52 & 66.44 & 3.478 \\
\hline
\end{tabular}

The higher DM-yield/ha and grain yield/ha of SNK 2950 originated from a slightly higher plant density. The lower DM-yield/ha of CRN 4502 can be attributed to low prolificacy and tillering of this cultivar. The differences in DM-yield/ha and grain yield/ha between cultivars probably did not have an effect on animal performance until the latter stages of the grazing period. The low percentage of DM utilized on CRN 4512 can probably be attributed to higher values for ADF (and NDF) and lower values for DOM observed for this cultivar. The composition of feed samples is presented in Table 2. 
Table 2 Composition of feed samples during the grazing period (\%).

\begin{tabular}{lllllll}
\hline & 1) PAN 6364 & 2) SNK 2950 & 3) CRN 4512 & 4) CRN 4502 & \multicolumn{2}{l}{ Differences } \\
\hline May - CP & 11.63 & 12.51 & 15.67 & 8.53 & $3>4$ & $* *$ \\
May - ADF & 15.64 & 16.66 & 23.54 & 10.26 & $3>4$ & $* *$ \\
May - DOM & 76.48 & 75.73 & 66.6 & 81.71 & $1,2,4>3 * *$ \\
June - CP & 8.16 & 10.48 & 10.37 & 8.78 & NS & \\
June - ADF & 21.79 & 22.69 & 22.95 & 11.4 & NS \\
June - DOM & 76.74 & 71.28 & 67.82 & 79.6 & NS \\
July - CP & 9.41 & 9.27 & 13.42 & 11.91 & NS & $*$ \\
July - ADF & 31.8 & 22.49 & 39.04 & 24.95 & $3>2$ & NS \\
July - DOM & 65.32 & 69.96 & 59.92 & 68.62 & & \\
\hline
\end{tabular}

$* \mathrm{P}<0.05 ; \quad * * \mathrm{P}<0.01 ; \quad \mathrm{NS}=$ not significant

The crude protein $(\mathrm{CP})$ content of feed samples of CRN 4512 was significantly higher $(\mathrm{P}<0.01)$ than that of CRN 4502 during the first month. The CP content of CRN 4512 tended to be higher $(\mathrm{P}>0.05)$ than that of other cultivars during the grazing period. The high CP content of CRN 4512 may be explained by the negative relationship between leaf- and grain nitrogen concentration and prolificacy of cultivars observed by Adriaanse (1990), and these relationships may be genetically linked to prolificacy. The tendency of CP to decrease as the grazing period progressed is in accordance with the findings of Lamm \& Ward (1981), Russell (1986) and Esterhuyse et al. (1991b). The lower CP content of PAN 6364, CRN 4512 and CRN 4502 in the second month of the grazing period could have been caused by adverse weather which resulted in wet and muddy conditions. Diet selection of fistulated ewes could probably have been affected in these conditions which resulted in a lower CP content of feed samples. An increase in CP content of feed samples was observed for these three cultivars during the third month of the grazing period. The higher ADF content and lower DOM content of CRN 4512 did not have a detrimental effect if compared to animal performance of the other cultivars. The tendency of ADF to increase as the grazing period progressed, is in accordance with the findings of Lamm \& Ward (1981). The tendency of DOM to decrease as the grazing period progressed, is in accordance with the findings of Esterhuyse et al. (1991b). Average mass of lambs $(\mathrm{kg}), \mathrm{ADG}$ of lambs and ADG of ewes (g/day) are presented in Table 3.

Table 3 Average mass of lambs (kg), ADG of lambs and ADG of ewes (g/day)

\begin{tabular}{lllllll}
\hline & 1) PAN 6364 & 2) SNK 2950 & 3) CRN 4512 & 4) CRN 4502 & \multicolumn{2}{l}{ Differences } \\
\hline Day 61 & 23.87 & 25.44 & 26.36 & 22.46 & $3>4$ & $*$ \\
Day 72 & 25.49 & 27.27 & 28.69 & 23.63 & $2>4,3>4$ & $*$ \\
Day 82 & 28.05 & 30.37 & 29.81 & 25.56 & $2>4,3>4$ & $*$ \\
ADG Day 72 & 177.78 & 197.92 & 218.19 & 155.83 & & \\
ADG Day 82 & 187.32 & 211.59 & 205.24 & 160.37 & & \\
Ewe ADG Day 72 & 106.53 & 110.69 & 131.39 & 96.39 & & \\
\hline
\end{tabular}
${ }^{*} \mathrm{P}<0.05$

The average mass of lambs grazing CRN 4512 tended to be higher than other cultivars during the first 49 days of the grazing period but differences between cultivars were not significant $(\mathrm{P}>0.05)$. Significant differences $(\mathrm{P}<0.05)$ in average mass of lambs occurred from Day 61 onwards with lambs grazing CRN 4512 and SNK 2950 attaining the highest average mass. Lambs grazing CRN 4512 attained the highest ADG during the first 72 days and were probably disadvantaged during the last few weeks of the grazing period due to a lower plant density and DM-yield. The ADG of lambs in this study was slightly lower than that of Moore \& Müller (1994) and Havenga (1997) attained with grain yields of 4-5 t/ha. No significant differences occurred in the average mass of ewes grazing different cultivars during the grazing period. Ewes grazing CRN 4512 attained the highest ADG during the first 72 days of the grazing period. No significant differences occurred in the milk production of ewes between cultivars during the grazing period, except for Week 15 of lactation. During Week 15 the milk production of ewes grazing CRN 4512 (537.49 $\mathrm{g}$ /day) was significantly higher $(\mathrm{P}<0.05)$ than that of ewes grazing CRN 4502 (219.97 g/day). The milk production response after introduction to maize foggage tended to be higher for ewes grazing CRN 4512 and 
Short paper and poster abstracts: $38^{\text {th }}$ Congress of the South African Society of Animal Science

SNK 2950 than for ewes grazing the other two cultivars. No significant differences occurred in wool fibre diameter of ewes between cultivars after completion of the grazing period.

\section{Conclusion}

Maize cultivars can differ in nutritive value when utilized as maize foggage and this has a definite effect on various aspects of sheep production. Further research, which may include more cultivars cultivated at different localities, is necessary to identify cultivars, which may sustain higher levels of animal performance. In general, the utilization of maize foggage by ewes and their lambs during the critical winter months in the North Eastern Free State, can play a significant role in bridging the gap in fodder flow usually experienced at this time of year.

\section{References}

Adriaanse, F.G., 1990. Ph.D Thesis, Univ. of the Orange Free State, Bloemfontein.

Esterhuyse, C.D., Niemand, S.D. \& Meissner, H.H., 1991b. S. Afr. J. Anim. Sci. 21, 149.

Ferreira, A.V., 1992. M.Sc. (Agric) Thesis, University of Orange Free State, Bloemfontein.

Havenga, C.J., 1997. M. Inst. Agrar. (Pasture Science) Thesis. University of Pretoria, Pretoria.

Lamm, W.D. \& Ward, J.K., 1981. J. Anim. Sci. 52, 954.

Moore, A. \& Müller, O., 1994. Nooitgedacht Boeredaglesings. 48-59.

Russell, J.R., 1986. Anim. Feed. Sci. \& Techn. 14, 11.

Schoonraad, H.M.I., 1985. M.Sc. (Agric.) Thesis, University of Pretoria, Pretoria. 